ISSN 1678-3921

Journal homepage: www.embrapa.br/pab

For manuscript submission and journal contents, access: www.scielo.br/pab

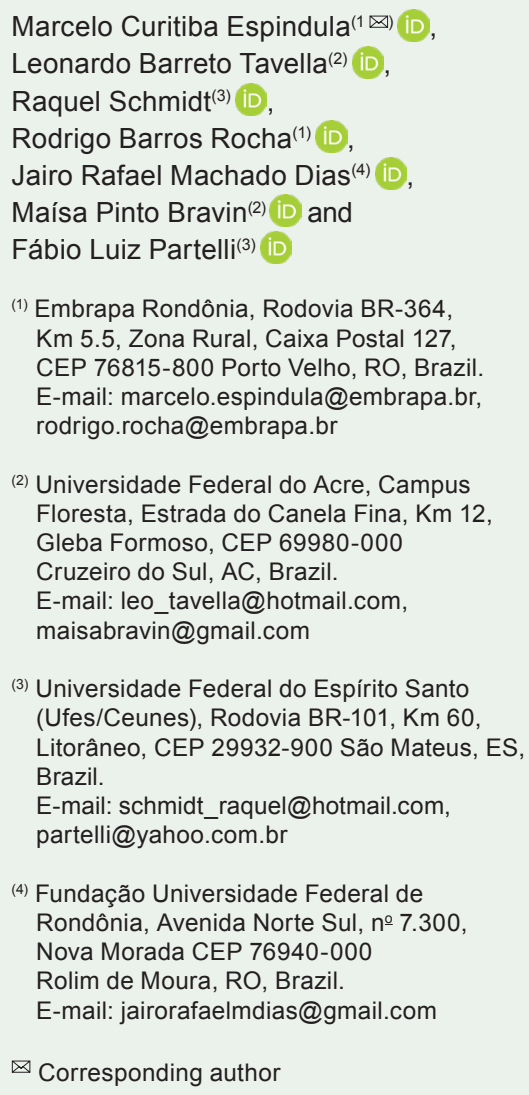

(2) Universidade Federal do Acre, Campus Floresta, Estrada do Canela Fina, Km 12 Gleba Formoso, CEP 69980-000 Cruzeiro do Sul, AC, Brazil. E-mail: leo_tavella@hotmail.com, maisabravin@gmail.com

(3) Universidade Federal do Espírito Santo (Ufes/Ceunes), Rodovia BR-101, Km 60, Litorâneo, CEP 29932-900 São Mateus, ES, Brazil.

E-mail: schmidt_raquel@hotmail.com, partelli@yahoo.com.br

(4) Fundação Universidade Federal de Rondônia, Avenida Norte Sul, no 7.300 , Nova Morada CEP 76940-000 Rolim de Moura, RO, Brazil. E-mail: jairorafaelmdias@gmail.com

$\bowtie$ Corresponding author

Received

April 28, 2021

Accepted

September 09, 2021

How to cite

ESPINDULA, M.C.; TAVELLA, L.B SCHMIDT, R.; ROCHA, R.B.; DIAS, J.R.M.; BRAVIN, M.P.; PARTELLI, F.L. Yield of robusta coffee in different spatial arrangements. Pesquisa Agropecuária Brasileira, v.56, e02516, 2021. DOI: https://doi.org/10.1590/ S1678-3921.pab2021.v56.02516.

\section{Yield of robusta coffee in different spatial arrangements}

\begin{abstract}
The objective of this work was to determine the contribution of the number of stems to the composition of individual plant yield, and to individual and overall robusta coffee (Coffea canephora) yield at different planting densities, using a fixed number of stems per plant. The experiment was carried out in two phases. The first phase was performed from 2011 to 2015 , in the municipality of Ouro Preto do Oeste, in the state of Rondônia (RO), Brazil, to evaluate different numbers of stems per plant $(1,2,3,4,5$, and 6). The second phase was conducted from 2013 to 2018, in the municipality of Alta Floresta D'Oeste, RO, to evaluate plant densities (at 1,666, 1,904, 2,222, 2,666 , and 3,333 plants ha- ${ }^{-1}$, with an initial density of four stems per plant in all treatments. The increase of number of stems per plant promotes a quadratic response to the average and cumulated yield of coffee plants, and the maximum yield is attained with four stems per plant. The number of stems should not exceed four, to avoid their tipping during years of high production. Plant density of 3,333 plants per hectare, with 4 stems per plant and $1 \mathrm{~m}$ spacing, promotes the reduction of individual plant yield; however, it results in higher overall crop yield.
\end{abstract}

Index terms: Coffea canephora, plant density, orthotropic stem, Amazon.

\section{Produtividade de cafeeiro robusta em diferentes arranjos espaciais}

Resumo - O objetivo deste trabalho foi determinar a contribuição do número de hastes para a composição da produtividade individual das plantas e a produtividade individual e geral de cafeeiros robusta (Coffea canephora), em diferentes densidades de plantio, utilizando-se um número fixo de hastes por planta. $\mathrm{O}$ experimento foi realizado em duas fases. A primeira fase foi realizada entre 2011 e 2015, no município de Ouro Preto do Oeste, no estado de Rondônia (RO), para avaliar diferentes números de hastes por planta (1, 2, 3, 4, 5 e 6). A segunda fase foi conduzida entre 2013 e 2018, no município de Alta Floresta D'Oeste, RO, para avaliar densidades de plantio (a 1.666, 1.904, $2.222,2.666$ e 3.333 plantas por hectare), tendo-se utilizado a densidade inicial de quatro hastes por planta em todos os tratamentos. O incremento do número de hastes por planta promove resposta quadrática à produtividade média e acumulada dos cafeeiros, e a máxima produtividade é obtida com quatro hastes por planta. O número de hastes não deve exceder quatro, para evitar seu tombamento durante os anos de alta produção. A densidade de 3.333 plantas $\mathrm{ha}^{-1}$, com quatro hastes por planta e espaçamento de um metro, promove redução da produtividade individual das plantas, no entanto, resulta em maior produtividade geral da lavoura.

Termos para indexação: Coffea canephora, densidade de plantas, hastes ortotrópicas, Amazônia. 


\section{Introduction}

The spatial arrangement of Conilon or Robusta coffee cultivars (Coffea canephora Pierre ex Froehner) is defined as the combination of the number of stems per plant and the density of plants in the cultivation area, and studies showed that spacing reduction and, consequently, the increase of the number of stems per hectare, resulted in a positive effect on coffee yield (Verdin Filho et al., 2014). These authors studied spacing combinations that resulted in densities ranging from 6,666 to 20,000 stems per hectare.

However, most of the plantations carried out from the 2010s on, in the Brazilian Amazon, used coffee plants from the robusta botanical group and/ or intraspecific hybrids originating from the crossing between genotypes of Conilon and Robusta Groups. In this region, coffee plants have been grown with combinations of planting spacing and number of stems that result in stem densities less than 11,000 (Dubberstein et al., 2017b; Silva et al., 2019; Espindula et al., 2020; Moraes et al., 2020). In this case, genotypes of the Robusta Group and hybrids naturally show higher vegetative vigor than those of the variety of Conilon Group (Souza et al., 2015). The high vegetative growth under the Amazon conditions, where annual precipitation can exceed $2,500 \mathrm{~mm}$ and the average annual temperature is about $25^{\circ} \mathrm{C}$ (Alvares et al., 2013), tends to accelerate the development of coffee plants, especially in irrigated crops (Dubberstein et al., 2017a; Bazoni et al., 2020).

Besides genetic and environmental factors, the spatial arrangements of coffee plants are also defined according to the management and cultural practices, such as the use of fertilization (Bragança et al., 2009), rainfed cultivation system (Verdin Filho et al., 2014), and the use of agricultural implements, to carry out management practices. Larger spacing between rows and shorter spacing within rows are required in mechanized cultivations. The spacing for $C$. canephora of the Conilon Group can reach up to $3.5 \mathrm{~m}$ between rows and $0.5 \mathrm{~m}$ between plants in the row (Souza et al., 2020). However, smaller spacings of up to $2 \times 1 \mathrm{~m}$ can also be used for nonmechanized genotypes cultivations of the Conilon Group (Verdin Filho et al., 2014).

In general, agronomic studies have shown that the increase of planting density reduces the individual yield, but increases the overall yield per area, in perennial fruit crops such as citrus (Azevedo et al., 2015) and pear (Pasa et al., 2015). However, the spacing for C. canephora plants is defined according to the number of stems per hectare, which depends on the number of stems per plant, defined in the first year of cultivation by the early induction, or even free growth (Schmidt et al., 2015; Espindula et al., 2020).

The objective of this work was to determine the contribution of the number of stems to the composition of individual plant yield of Coffea canephora, and the individual and overall coffee yield, at different planting densities using a fixed number of stems per plant.

\section{Materials and methods}

The experiment was developed in two phases: the first one evaluated the effect of the number of stems for the composition of the individual yield of coffee plants; the second one evaluated different plant densities, using the ideal number of stems defined in the first phase.

The first phase experiment was carried out at the experimental field of Embrapa Rondônia, in the munipality of Ouro Preto do Oeste $\left(10^{\circ} 45^{\prime} 43^{\prime \prime} \mathrm{S}\right.$, $62^{\circ} 15^{\prime} 10^{\prime \prime} \mathrm{W}$, at $300 \mathrm{~m}$ altitude), in the state of Rondônia, Brazil, from July 2011 to July 2015. The predominant climate in the region is Am type (Köppen-Geiger's classification), with $25^{\circ} \mathrm{C}$ mean annual temperature, and 1,900-2,200 $\mathrm{mm}$ per year mean precipitation (Alvares et al., 2013). The soil is classified as a clayey-textured Latossolo Vermelho-Amarelo eutrófico, according to Brazilian system of soil classification (Santos et al., 2013), i.e., an Oxisol (Soil Survey Staff, 2014), whose attributes at $0.00-0.20 \mathrm{~m}$ soil depth, at the beginning of the experiment, were: $6.0 \mathrm{pH}\left(\mathrm{H}_{2} \mathrm{O}\right) ; 14 \mathrm{mg} \mathrm{dm}^{-3} \mathrm{P}$; $0.32 \mathrm{cmol}_{\mathrm{c}} \mathrm{dm}^{-3} \mathrm{~K} ; 5.19 \mathrm{cmol}_{\mathrm{c}} \mathrm{dm}^{-3} \mathrm{Ca} ; 1.47 \mathrm{cmol}_{\mathrm{c}} \mathrm{dm}^{-3}$ $\mathrm{Mg} ; 3.47 \mathrm{cmol}_{\mathrm{c}} \mathrm{dm}^{-3} \mathrm{H}+\mathrm{Al} ; 10.45 \mathrm{cmol}_{\mathrm{c}} \mathrm{dm}^{-3} \mathrm{CEC}$; $0.0 \mathrm{cmol}_{\mathrm{c}} \mathrm{dm}^{-3} \mathrm{Al} ; 1.91 \mathrm{dag} \mathrm{kg}^{-1} \mathrm{SOM}$; and $67 \%$ bases saturation $(\mathrm{V})$.

The area has been cultivated with six genotypes (clones); however, only four C. canephora genotypes of growth habit typical of hybrid plants of the Robusta and Conilon groups, were evaluated. The clones 59, 100, 193, and 199, which belong to the Embrapa breeding program were planted in November 2008, at $3 \mathrm{~m}$ spacing between rows and $2 \mathrm{~m}$ between plants. The clones 193 and 199 were launched as monoclonal varieties in 2019, as registered cultivar names BRS 3193 and BRS 2299, respectively (Teixeira et al., 2020). 
Planting was carried out using the "in-line clone" system, in which the plants of the same planting row are formed by the same genotype.

The coffee plants were subjected to drastic pruning in July 2011, to standardize the number of stems per plant. All orthotropic stems were removed at $30 \mathrm{~cm}$ height from the ground level during pruning. New stems (sprouts) appeared after pruning, and they were selected to compose the new plant canopy according to the number of stems required for each treatment.

The experiment was conducted in split-plot in time $(3 \times 6)$, in which main plots corresponded to three evaluation seasons (2013, 2014, and 2015), and subplots corresponded to the number of stems $(1,2,3,4,5$, and 6 stems per coffee plant). The experimental design was carried out in randomized complete block, with four replicates, in which each block consisted of a C. canephora genotype to attain an average behavior for the genotype group. The experimental subplot consisted of six plants, with two plants belonging to the borders and four useful plants.

The nutritional management of the plants was carried out through the manual application of fertilizers split into four applications during the rainy season (October, December, January, and March), based on the soil analysis and the expected production of 60,100 , and 60 bags per hectare of $60 \mathrm{~kg}$ of processed beans, in the 2013, 2014, and 2015 crop seasons, respectively (Table 1). During the experiment, plants were managed according to the technical recommendations for cultivation under rainfed conditions, without supplementary irrigation (Marcolan et al., 2009).

Plant vegetative and reproductive characteristics were determined in May of each year, that is, the fruit harvest period. The following characteristics were evaluated: height of orthotropic stems (m), attained by measuring from the point of stem insertion to the plant apex; diameter of orthotropic stems $(\mathrm{mm})$, determined by a digital caliper, at $10 \mathrm{~cm}$ height from the point of the main stem insertion; number of plagiotropic branches per plant, determined by direct counting all branches of the plant; plant canopy diameter (m), determined using canopy measurements in the east-west and northsouth direction, at the height of the middle third of the plant; individual production of fresh fruit ( $\mathrm{kg}$ per plant), obtained through manual and individual plant harvesting, when there were more than $90 \%$ of cherry fruit; cumulated individual production and average production ( $\mathrm{kg}$ per plant), attained by the sum and average of the three evaluated harvests.

The data were subjected to the analysis of variance, at $5 \%$ probability, to evaluate the significance of the interaction between the factors, using the statistical program Sisvar (Ferreira, 2014). The Tukey's test, at $5 \%$ probability, was applied to compare the means between years, and the regression analysis was used to quantify the effects of the number of stems within each year.

The second phase of the experiment was conducted at a private rural property, in the municipality of Alta Floresta D'Oeste $\left(12^{\circ} 04^{\prime} 00^{\prime \prime} \mathrm{S}, 62^{\circ} 02^{\prime} 14^{\prime \prime} \mathrm{W}\right.$, at 431 $\mathrm{m}$ altitude), in the state of Rondônia, Brazil, from November 2013 to June 2018.

The soil in the study area is classified as Argissolo Vermelho-Amarelo eutrófico, according to Brazilian system of soil classification (Santos et al., 2013), i.e., an Ultisol (Soil Survey Staff, 2014), which has been cultivated with $C$. canephora plants for the last 10 years. The soil chemical analysis at $0.00-0.20 \mathrm{~m}$ depth, in the beginning of the study, indicated the following

Table 1. Amounts of macronutrients applied annually to Coffea canephora plants for four years, after drastic pruning of orthotropic stem renewal, in the municipality of Ouro Preto do Oeste, in the state of Rondônia, Brazil.

\begin{tabular}{lcccccc}
\hline Year $^{(1)}$ & $\mathrm{N}$ & $\mathrm{P}$ & $\mathrm{K}$ & $\mathrm{Ca}$ & $\mathrm{Mg}$ & $\mathrm{S}$ \\
\hline & & & (g per plant) & & \\
$2011 / 2012^{(2)}$ & 70 & 25 & 70 & 0 & 0 & 18 \\
$2012 / 2013$ & 150 & 45 & 150 & 0 & 5 & 75 \\
$2013 / 2014$ & 200 & 50 & 200 & 20 & 10 & 75 \\
$2014 / 2015$ & 150 & 45 & 150 & 20 & 10 & 180 \\
\hline
\end{tabular}

${ }^{(1)}$ Fertilizers were applied in October and December of a year, and January and March of the following year. ${ }^{(2)}$ In the first year after stem renewal pruning, there is only vegetative growth, and no fruit production. 
results: $6.8 \mathrm{pH}\left(\mathrm{H}_{2} \mathrm{O}\right) ; 5 \mathrm{mg} \mathrm{dm}^{-3} \mathrm{P} ; 0.25 \mathrm{cmol}_{\mathrm{c}} \mathrm{dm}^{-3} \mathrm{~K}$; $8.6 \mathrm{cmol}_{\mathrm{c}} \mathrm{dm}^{-3} \mathrm{Ca} ; 2.25 \mathrm{cmol}_{\mathrm{c}} \mathrm{dm}^{-3} \mathrm{Mg} ; 2.48 \mathrm{cmol}_{\mathrm{c}} \mathrm{dm}^{-3}$ $\mathrm{H}+\mathrm{Al} ; 13.58 \mathrm{cmol}_{\mathrm{c}} \mathrm{dm}^{-3} \mathrm{CEC} ; 0.0 \mathrm{cmol}_{\mathrm{c}} \mathrm{dm}^{-3} \mathrm{Al} ; 3.57$ dag $\mathrm{kg}^{-1} \mathrm{SOM}$; and $82 \%$ bases saturation (V). Tree stumps were removed from the area before planting, and planting furrows of $50 \mathrm{~cm}$ depth and $40 \mathrm{~cm}$ width were opened at $3 \mathrm{~m}$ distance from each other.

The experiment was carried out in a split-plot in time $(3 \times 5)$, in which main plots corresponded to three evaluation seasons (2016, 2017, and 2018), and subplots were formed by coffee plant densities at 1,666, 1,904, $2,222,2,666$, and 3,333 plants per hectare, which corresponded to spacings at $2.00,1.75,1.50,1.25$, and $1.00 \mathrm{~m}$ between plants in the row, with $3 \mathrm{~m}$ spacing between rows for all densities. The experimental design consisted of randomized complete blocks, with five replicates, in which each block was represented by a C. canephora genotype planted in the "in-line clone" system to obtain the average behavior of the genotype group. The genotypes were five commercial cultivar of nondefined genetic origin, with growth habit typical of hybrid plants - named AS1 and P50 (small sized plants), and AS2, AS3 and AS4 (medium and high sized plants) - from the Robusta and Conilon groups. The experimental subplot consisted of eight plants, two of them considered the borders, and six considered as useful plants.

Apical pruning was applied to coffee plants at 90 days after planting, to allow of the emission of orthotropic stems (Schmidt et al., 2015). The excess orthotropic stems was eliminated at approximately 90 days after the apical pruning, to maintain the average of four stems per plant.
The plant nutritional management was carried out through the manual application of fertilizers split into five applications during the rainy season (October, November, December, January, and March), based on the soil analysis and on the expected production of 100 bags of $60 \mathrm{~kg} \mathrm{ha}^{-1}$ processed beans, in the 2016 season, and over 140 bags of $60 \mathrm{~kg} \mathrm{ha}^{-1}$ in the 2017 and 2018 seasons (Table 2). During the experimental period, plants were managed according to the technical recommendations for the crop (Marcolan et al., 2009).

Coffee plants were irrigated during the dry months (May to October) in all years, using a drip irrigation system. Irrigation water depth was $3 \mathrm{~mm}$ per day applied in a 2-day irrigation shift, during the planting stage, and $6 \mathrm{~mm}$ per day applied in a 4-day irrigation shift, during the reproductive stage $(2015,2016$, and 2017). These amounts of water were based on the regional average evapotranspiration during the dry season.

Fruit harvest was carried out in May of each year. At this stage, fresh fruit of the plot were harvested manually and weighed. Subsequently, a sample of $3 \mathrm{~L}$ fruit was sent for drying and processing, to determine the processing yield ( $\mathrm{kg}$ fresh coffee fruit per $\mathrm{kg}$ processed beans). The fruit production and yield data allowed of the following variable estimations: individual grain production ( $\mathrm{kg}$ per plant); overall grain production (bags of $60 \mathrm{~kg} \mathrm{ha}^{-1}$ ); individual and overall production obtained from the sum and average production, in the three evaluated harvests.

The data were subjected to the analysis of variance, at $5 \%$ probability, to evaluate the significance of the interaction between factors, using the statistical program Sisvar (Ferreira, 2014). The Tukey's test, at

Table 2. Amounts of macronutrients applied annually to Coffea canephora plants during five years of cultivation, in the municipality of Alta Floresta D’Oeste, in the state of Rondônia, Brazil.

\begin{tabular}{|c|c|c|c|c|c|c|}
\hline Year $^{(1)}$ & $\mathrm{N}$ & $\mathrm{P}$ & $\mathrm{K}$ & $\mathrm{Ca}$ & $\mathrm{Mg}$ & S \\
\hline & \multicolumn{6}{|c|}{ (g per plant) } \\
\hline $2013 / 2014^{(2)}$ & 50 & 15 & 40 & 0 & 0 & 10 \\
\hline $2014 / 2015$ & 100 & 30 & 100 & 0 & 0 & 10 \\
\hline $2015 / 2016$ & 125 & 35 & 125 & 10 & 3 & 15 \\
\hline $2016 / 2017$ & 125 & 35 & 120 & 10 & 3 & 15 \\
\hline $2017 / 2018$ & 150 & 45 & 150 & 10 & 3 & 15 \\
\hline
\end{tabular}

${ }^{(1)}$ October, November, and December of one year, and January and March of the following year. ${ }^{(2)}$ The period from November 2013 to June 2015 corresponds to the stage of formation of coffee plants, and the picking of the first year (2015) was disregarded because of the formation pruning. 
$5 \%$ probability, was applied to compare the means of years, and the regression analysis was performed for the effects of planting densities within each year. Regression analyses were also adjusted for individual and overall average yields (three seasons).

\section{Results and discussion}

The height and diameter of orthotropic stems were higher in the 2015 harvest (third harvest), regardless of the number of stems used (Figure $1 \mathrm{~A}, \mathrm{~B}$ ). Considering the treatment means, $17.09 \%$ increase of the stem height was observed from the 2013 to 2014 season (second harvest), and $22.16 \%$, from the 2014 to 2015 season (third harvest), while stem diameter increase also reached $16.56 \%$ from the 2013 to 2014 season (second harvest), and $10.29 \%$, from the 2014 to 2015 season (third harvest).

This behavior of increasing over time is explained by the natural growth of plants during their life cycle. However, it is important to consider that, the height and diameter of the stems were both influenced by the years and by the number of stems per plant. Stem height showed a quadratic effect with the number of orthotropic stems per plant, and the maximum height points were attained between four and five stems per plant (Figure $1 \mathrm{~A}$ ). Conversely, the increase of the number of stems resulted in a linear decrease of the diameter of stems, in all evaluated years (Figure $1 \mathrm{~B}$ ).

These results lead us to infer that there is a competition between stems for resources, especially light. In this case, the competition for light stimulates the stem elongation and, consequently, a reduction of their radial growth regulated by the growth hormones, that stimulate the apical growth of plants (Martinez et al., 2007; Pereira et al., 2011). However, the effect of more stems per plant (5 and 6 stems) on plant growth were also negative, which is attributed to the competition for resources, such as water, nutrients, and carbohydrates, caused by an imbalance of the leaf area due to excess orthotropic stems (DaMatta et al., 2007). Besides, no increase of stem height was observed with 5 and 6 stems per plant. The lowest increase in diameter with these treatments may be related to the competition for carbohydrates caused by the excess stems, which was also observed by Nacif (1997). A smaller diameter associated with longer stem height may weaken the support of the productive branches, leading to tipping. For this reason, the empirical trend of using a maximum of three stems per plant has been observed in the field.

Plants allowed to grow with only one stem showed similar numbers of plagiotropic branches in the years 2013, 2014, and 2015. However, the use of two or more stems led to the highest number of branches in the first harvest (2013) and to the lowest values in the third harvest (2015) (Figure 1 C). An opposite behavior was observed for canopy diameter, which was higher in the 2015 harvest, differing from the previous years (2013 and 2014), in plants that had three or more orthotropic stems (Figure $1 \mathrm{D}$ ).

The increase of the number of stems promoted a linear increase of the number of plagiotropic branches in all harvests (Figure $1 \mathrm{C}$ ), as well as an increasing linear effect on the canopy diameter in the first harvest (2013), and a quadratic effect in other harvests (2014 and 2015), with the maximum increase point between 5 and 6 stems (Figure 1 D).

The increase of the number of plagiotropic branches as a function of an increase of the number of orthotropic stems did not directly affect the canopy composition of plants with more than 5 orthotropic stems, which can be attributed to the effect of self-shading that inhibits the growth of plagiotropic branches (Martinez et al., 2007; Pereira et al., 2011). The effect of competition between branches for photoassimilates should also be considered, as previously reported by DaMatta et al. (2007).

Fruit production was higher in the second harvest (2014) than in the first and third harvests, regardless of the number of stems, indicating a biennial production effect. No difference for production was observed between the first and third harvests, regardless of the number of stems (Figure 1 E). The biennial production found in the present study may be related to the rainfed cultivation system, which restricts plant growth to the rainy period and leads to leaf abscission in the dry season, to prevent water loss (Dardengo et al., 2018), which results in a lower fruit production. Also, the phenomenon of biennial bearing observed may have resulted from the fact that high yields in one year deplete the nutrients to form new fruit buds in the following year, according to Dennis Jr. (2003). Similarly to our findings, the biennial production phenomenon has been also observed for robusta coffee (Akpertey et al., 2019), kola (Akpertey et al., 2017), and apple (McArtney et al., 2013). 

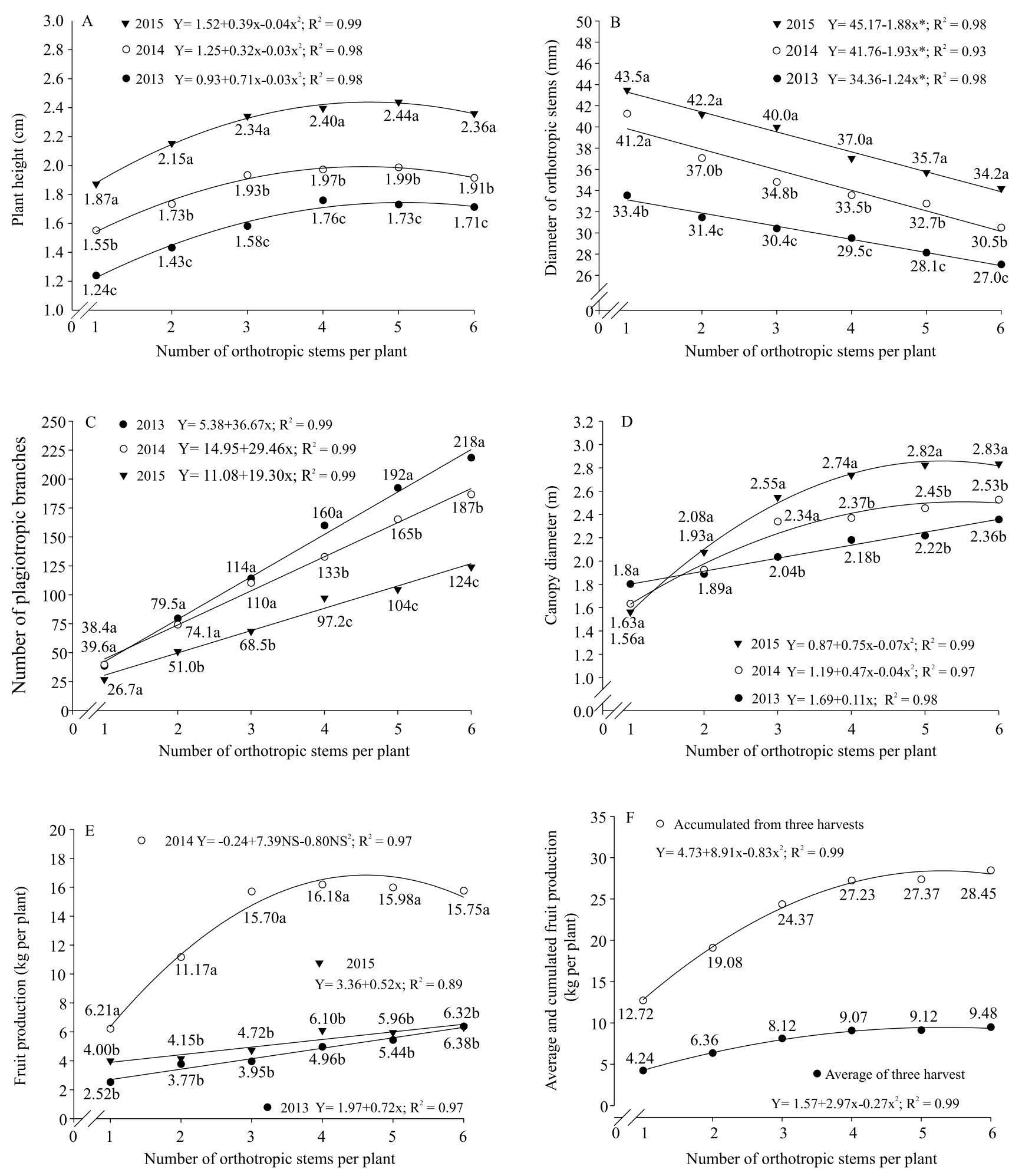

Figure 1. Height (A) and diameter of orthotropic stems (B), number of plagiotropic branches (C), canopy diameter (D), fruit production per year (E), and average and cumulated production of three harvests (F) of Coffea canephora plants conducted with different number of orthotropic stems, in the municipality of Ouro Preto do Oeste, in the state of Rondônia, Brazil. Means followed by the equal letters vertically do not differ from each other, by the Tukey's test, at 5\% probability. Coefficients of variation (\%): $\mathrm{A}=8.21 ; \mathrm{B}=9.32 ; \mathrm{C}=21.29 ; \mathrm{D}=13.20 ; \mathrm{E}=27.97$. 
The number of stems showed a linear effect on fruit production, in the first and third harvests (2013, 2015), and a quadratic effect on the second harvest (2014), with no increase or decrease of production with more than four stems per plant (Figure $1 \mathrm{E}$ ). As a result, the average and cumulated production also showed a quadratic behavior (Figure 1 F). Similarly, no significant increases were observed, when using more than four stems per plant, as noticed in the 2014 harvest for these two last characteristics. These results differ from those attained by Verdin Filho et al. (2014), who tested spacings and number of stems in rainfed systems, and observed production gains using 5 stems per plant at $3.0 \times 1.0 \mathrm{~m}$ and $3.5 \times 1.5 \mathrm{~m}$ spacings. Although the species used in that study were the same as those of the present work (C. canephora), the botanical groups were different. The coffee plants tested by those authors were from the Conilon Group, while the genotypes used in the present study are hybrids from the crossing between Conilon and Robusta Groups, which have growth patterns more similar to the plants of the Robusta Group.

The production results of the present study and the observed decrease of the radial growth of stems (Figure $1 \mathrm{~B}$ ), when the number of stems per plant increased, suggests that the number of stems should not exceed four to avoid their tipping during years of high production.

Plantations in which agricultural machinery and implements are used to carry out management practices also require the stems to be upright and not to bend towards the row; therefore, the use of the maximum three stems per plant is suggested, especially when using genotypes with slightly stiff stems (Espindula et al., 2019). Moreover, due to the reduced fruit production, the use of only one stem per plant should be studied for mechanical harvesting by self-propelled machines (Souza et al., 2020) because more than a stem can hinder fruit harvesting efficiency.

The first harvest (2016) from the plant density study, had the lowest mean yield, in comparison with the following two seasons, with no difference between the second and third harvests, regardless of spacing (Figure 2 A, B). The absence of difference between the second and third seasons indicates no biennial production between the second and third harvests, which may be attributed to the management adopted for the crop, such as irrigation, genetic material under study, and plant age (Rodrigues et al., 2013), as well as nutrition (Valadares et al., 2013) and programmed pruning cycle for production (Verdin Filho et al., 2014).

The individual yield of coffee trees decreased with increasing planting density, in all the evaluated seasons (Figure 2 A). However, the overall yield increased linearly with the increase in planting density, in all the harvests (Figure 2 B). Because of this behavior, the average individual yield decreased, and the overall average yield increased with the increase in planting
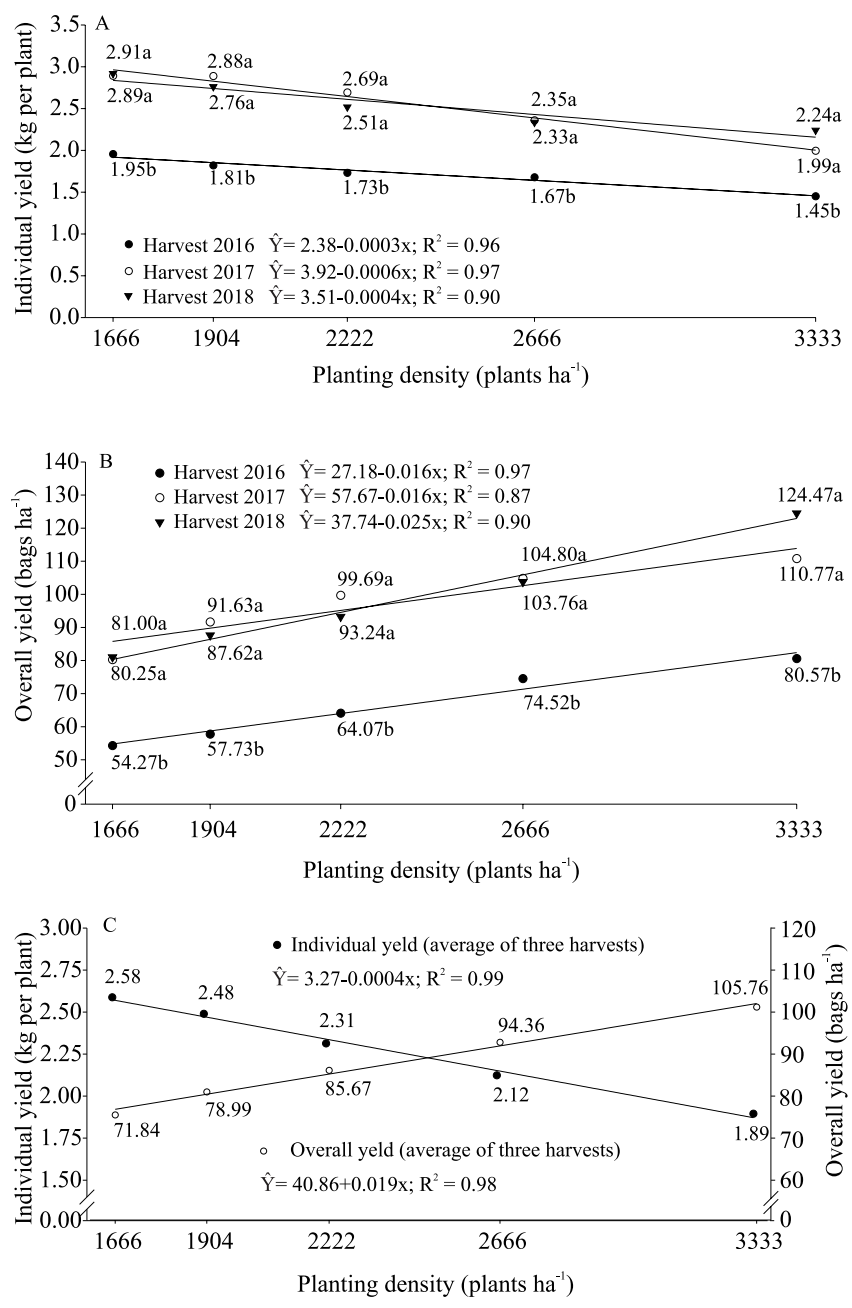

Figure 2. Individual (A) and overall yield (B) in three seasons, and average individual and overall yield of three seasons (C) of Coffea canephora plants, at different planting densities, in the municipality of Ouro Preto do Oeste, in the state of Rondônia, Brazil. Means followed by equal letters vertically do not differ from each other, by the Tukey's test, at $5 \%$ probability. Coefficients of variation (\%): $\mathrm{A}=20.91$; $\mathrm{B}=22.98$. 
density (Figure $2 \mathrm{C}$ ). The average yield per plant decreased from $2.58(3 \times 2 \mathrm{~m})$ to $1.89 \mathrm{~kg}$ of beans per plant $(3 \times 1 \mathrm{~m})$, and the overall yield increased from $71.84(3 \times 2 \mathrm{~m})$ to 105.76 bags per hectare $(3 \times 1 \mathrm{~m})$. The cumulative production of the three seasons reached 215.52 bags per hectare at $3 \times 2 \mathrm{~m}$ spacing, and 315.81 bags per hectare at $3 \times 1 \mathrm{~m}$ spacing, which represents an increase of more than 100 bags per hectare.

The results of the present work suggest that the spacing within the planting row of hybrid coffee plants from the crossings between Conilon and Robusta Groups, in the Brazilian Amazon conditions, should be a maximum of $1 \mathrm{~m}$, especially if the number of stems per plant is kept at a maximum of three, as suggested in this study. The possibility of using smaller spacings than $1 \mathrm{~m}$ for planting, in which the maximum number of stems is two stems per plant, and also using smaller inter-row spacings, should also be considered, as suggested by Verdin Filho et al. (2014) for nonmechanized crops.

\section{Conclusions}

1. The increase of the number of stems per plant promotes a quadratic response to the average and cumulated yield of Coffea canephora plants, and the maximum yield is attained with four stems per plant; the number of stems should not exceed four, to avoid their tipping during years of high production.

2. The individual yield of coffee trees decreases with increasing planting density, while the overall yield increases linearly with the increase of planting density, in all harvests; besides, the density of 3,333 plants per hectare, with four stems per plant and $1 \mathrm{~m}$ spacing, within the planting row of hybrid coffee plants from the crossings between Conilon and Robusta Groups, in the Brazilian Amazon conditions, promotes a reduction of the individual yield of plants, but results in a higher yield per crop area.

\section{Acknowledgments}

To Mr. Ademar Schmidt, for making his plantation available for the experiment; and to Consórcio Brasileiro de Pesquisa e Desenvolvimento do Café (CBP\&D/Café), for financial support (process number 02.13.02.046.00.04).

\section{References}

AKPERTEY, A.; ANIM-KWAPONG, E.; OFORI, A. Early selection for yield in robusta coffee based on juvenile growth traits. African Crop Science Journal, v.27, p.571-584, 2019. DOI: https://doi.org/10.4314/acsj.v27i4.3.

AKPERTEY, A.; DADZIE, A.M.; ADU-GYAMFI, P.K.K.; OFORI, A.; PADI, F.K. Effectiveness of juvenile traits as selection criteria for yield efficiency in kola. Scientia Horticulturae, v.216, p.264-271, 2017. DOI: https://doi.org/10.1016/j.scienta.2017.01.018.

ALVARES, C.A.; STAPE, J.L.; SENTELHAS, P.C.; GONÇALVES, J.L. de M.; SPAROVEK, G. Köppen's climate classification map for Brazil. Meteorologische Zeitschrift, v.22, p.711-728, 2013. DOI: https://doi.org/10.1127/09412948/2013/0507.

AZEVEDO, F.A.; PACHECO, C. de A.; SCHINOR, E.H.; CARVAlHO, S.A. de; CONCEIÇÃO, P.M. da. Produtividade de laranjeira Folha Murcha enxertada em limoeiro Cravo sob adensamento de plantio. Bragantia, v.74, p.184-188, 2015. DOI: https://doi.org/10.1590/1678-4499.0374.

BAZONI, P.A.; ESPINDULA, M.C.; ARAÚJO, L.F.B. de; VASCONCELOS, J.M.; CAMPANHARO, M. Production of cuttings and nutrient export by Coffea canephora in different periods in the Southwestern Amazon. Revista Brasileira de Engenharia Agrícola e Ambiental, v.24, p.162-169, 2020. DOI: https://doi.org/10.1590/1807-1929/agriambi.v24n3p162-169.

BRAGANÇA, S.M.; SILVA, E.B.; MARTINS, A.G.; SANTOS, L.P.; LANI, J.A.; VOLPI, P.S. Resposta do cafeeiro conilon à adubação de NPK em sistema de plantio adensado. Coffee Science, v.4, p.67-75, 2009.

DAMATTA, F.M.; RONCHI, C.P.; MAESTRI, M.; BARROS, R.S. Ecophysiology of coffee growth and production. Brazilian Journal of Plant Physiology, v.19, p.485-510, 2007. DOI: https://doi.org/10.1590/S1677-04202007000400014.

DARDENGO, M.C.J.D.; PEREIRA, L.R.; SOUSA, E.F. de; REIS, E.F dos. Yield, quality and water consumption of conilon coffee under irrigated and dryland managements. Coffee Science, v.13, p.272-282, 2018. DOI: https://doi.org/10.25186/cs.v13i3.1437.

DENNIS JR., F. Flowering, pollination and fruit set and development. In: FERREE, D.C.; WARRINGTON, I.J. (Ed.). Apples: Botany, production and uses. Cambridge: CAB International, 2003. p.153-166. DOI: https://doi.org/10.1079/9780851995922.0153.

DUBBERSTEIN, D.; PARTELLI, F.L.; DIAS, J.R.M.; ESPINDULA, M.C. Influência da adubação no crescimento vegetativo de cafeeiros na Amazônia sul ocidental. Coffee Science, v.12, p.197-206, 2017a.

DUBBERSTEIN, D.; PARTELLI, F.L.; SCHMIDT, R.; DIAS, J.R.M.; COVRE, A.M. Matéria seca em frutos, folhas e ramos plagiotrópicos de cafeeiros cultivados na Amazônia Ocidental. Coffee Science, v.12, p.74-81, 2017b.

ESPINDULA, M.C.; ARAÚJO, L.F.B. de; SCHMIDT, R.; DIAS, J.R.M.; ROCHA, R.B. Early induction of orthotropic shoots in 
Coffea canephora. Revista Ceres, v.67, p.281-287, 2020. DOI: https://doi.org/10.1590/0034-737x202067040005.

ESPINDULA, M.C.; TEIXEIRA, A.L.; ROCHA, R.B.; RAMALHO, A.R.; VIEIRA JÚNIOR, J.R.; ALVES, E.A.; DIOCLECIANO, J.M.; LUNZ, A.M.P.; SOUZA, F. de F.; COSTA, J.N.M.; FERNANDES, C. de F. Novas cultivares de cafeeiros Coffea canephora para a Amazônia Ocidental Brasileira: principais características. Porto Velho: Embrapa Rondônia, 2019. (Embrapa Rondônia. Comunicado técnico, 413).

FERREIRA, D.F. Sisvar: a guide for its Bootstrap procedures in multiple comparisons. Ciência e Agrotecnologia, v.38, p.109-112, 2014. DOI: https://doi.org/10.1590/S1413-70542014000200001.

MCARTNEY, S.; GREENE, D.; SCHMIDT, T.; YUAN, R. Naphthaleneacetic acid and ethephon are florigenic in the biennial apple cultivars Golden Delicious and York Imperial. HortScience, v.48, p.742-746, 2013. DOI: https://doi.org/10.21273/ HORTSCI.48.6.742.

MARCOLAN, A.L.; RAMALHO, A.R.; MENDES, A.M.; TEIXEIRA, C.A.D.; FERNANDES, C. de F.; COSTA, J.N.M.; VIEIRA JÚNIOR, J.R.; OLIVEIRA, S.J. de M.; FERNANDES, S.R.; VENEZIANO, W. Cultivo dos cafeeiros Conilon e Robusta para Rondônia. 3.ed. rev. e atual. Porto Velho: Embrapa Rondônia, 2009. 61p. (Embrapa Rondônia. Sistemas de produção, 33).

MARTINEZ, H.E.P.; AUGUSTO, H.S.; CRUZ, C.D.; PEDROSA, A.W.; SAMPAIO, N.F. Crescimento vegetativo de cultivares de café (Coffea arabica L.) e sua correlação com a produção em espaçamentos adensados. Acta Scientiarum. Agronomy, v.29, p.481-489, 2007. DOI: https://doi.org/10.4025/actasciagron. v29i4.404.

MORAES, M.S.; ROCHA, R.B.; TEIXEIRA, A.L; ESPINDULA, M.C.; SILVA, C.A.; LUNZ, A.M.P. Adaptability and stability of Coffea canephora Pierre ex Froehner genotypes in the Western Amazon. Ciência Rural, v.50, e20190087, 2020. DOI: https://doi.org/10.1590/0103-8478cr20190087.

NACIF, A. de P. Fenologia e produtividade do cafeeiro (Coffea arabica L.) cv. Catuaí, sob diferentes densidades de plantio e doses de fertilizante no Cerrado de Patrocínio-MG. 1997. 125p. Tese (Doctor Scientiae) - Universidade Federal de Viçosa, Viçosa.

PASA, M. da S.; FACHINELLO, J.C.; ROSA JÚNIOR, H.F. da; FRANCESCHI, É. de; SCHMITZ, J.D.; SOUZA, A.L.K. de. Performance of 'Rocha' and 'Santa Maria' pears as affected by planting density. Pesquisa Agropecuária Brasileira, v.50, p.126-131, 2015. DOI: https://doi.org/10.1590/S0100204X2015000200004.

PEREIRA, S.P.; BARTHOLO, G.F.; BALIZA, D.P.; SOBREIRA, F.M.; GUIMARÃES, R.J. Crescimento, produtividade e bienalidade do cafeeiro em função do espaçamento de cultivo. Pesquisa Agropecuária Brasileira, v.46, p.152-160, 2011. DOI: https://doi.org/10.1590/S0100-204X2011000200006.
RODRIGUES, W.N.; TOMAZ, M.A.; FERRÃO, R.G.; FERRÃO, M.A.G.; FONSECA, A.F.A. da; MARTINS, L.D. Crop yield bienniality in groups of genotypes of conilon coffee. African Journal of Agricultural Research, v.8, p.4422-4426, 2013. DOI: https://doi.org/10.5897/AJAR12.1999.

SANTOS, H.G. dos; JACOMINE, P.K.T.; ANJOS, L.H.C. dos; OLIVEIRA, V.A. de; LUMBRERAS, J.F.; COELHO, M.R.; ALMEIDA, J.A. de; CUNHA, T.J.F.; OLIVEIRA, J.B. de. Sistema brasileiro de classificação de solos. 3.ed. rev. e ampl. Brasília: Embrapa, 2013. 353p.

SCHMIDT, R.; DIAS, J.R.M.; ESPINDULA, M.C.; PARTELLI, F.L.; ALVES, E.R. Poda apical e vergamento da haste principal na formação de cafeeiros clonais. Coffee Science, v.10, p.266-270, 2015.

SILVA, D.R. da; SILVA, D.R. da; DAMACENO, J.B.D.; ANDRADE, R.A.; DOMINGUES, C.G.; SILVA, C.A. da; MARTINS, J.K.D. TRASPADINI, E.I.F.; DUBBERSTEIN, D.; DIAS, J.R.M. Compatibility test and agronomic performance of coffee genotypes (Coffea canephora Pierre ex Froehner) in the State of Rondônia, Brazil. Journal of Agricultural Science, v.11, p.162-170, 2019. DOI: https://doi.org/10.5539/jas.v11n15p162.

SOIL SURVEY STAFF. Keys to soil taxonomy. $12^{\text {th }}$ ed. Washington: USDA, 2014. 360p.

SOUZA, F. de F.; FERRÃO, L.F.V.; CAIXETA, E.T.; SAKIYAMA, N.S.; PEREIRA, A.A.; OLIVEIRA, A.C.B. de. Aspectos gerais da biologia e da diversidade genética de Coffea canephora. In: MARCOLAN, A.L.; ESPINDULA, M.C. (Ed). Café na Amazônia. Brasília: Embrapa, 2015. p.83-98.

SOUZA, G.S. de; LANI, J.A.; INFANTINI, M.B.; KROHLING, C.A.; SENRA, J.F. de B. Mechanized harvesting of 'Conilon' coffee clones. Pesquisa Agropecuária Brasileira, v.55, e01240, 2020. DOI: https://doi.org/10.1590/s1678-3921.pab2020.v55.01240.

TEIXEIRA, A.L.; ROCHA, R.B.; ESPINDULA, M.C.; RAMALHO, A.R.; VIEIRA JÚNIOR, J.R.; ALVES, E.A.; LUNZ, A.M.P.; SOUZA, F. de F.; COSTA, J.N.M.; FERNANDES, C. de F. Amazonian Robustas - new Coffea canephora coffee cultivars for the Western Brazilian Amazon. Crop Breeding and Applied Biotechnology, v.20, e323420318, 2020. DOI: https://doi.org/10.1590/1984-70332020v20n3c53.

VALADARES, S.V.; NEVES, J.C.L.; ROSA, G.N.G.P.; MARTINEZ, H.E.P.; VENEGAS, V.H.A.; LIMA, P.C. de. Produtividade e bienalidade da produção de cafezais adensados, sob diferentes doses de $\mathrm{N}$ e $\mathrm{K}$. Pesquisa Agropecuária Brasileira, v.48, p.296-303, 2013. DOI: https://doi.org/10.1590/ S0100-204X2013000300008.

VERDIN FILHO, A.C.; TOMAZ, M.A.; FERRÃO, R.G.; FERRÃO, M.A.G.; FONSECA, A.F.A. da; RODRIGUES, W.N. Conilon coffee yield using the programmed pruning cycle and different cultivation densities. Coffee Science, v.9, p.489-494, 2014. 